\title{
MATHEMATICS LEARNING THROUGH CHARACTER EDUCATION BASED ON INTEGRATED THEMATIC LEARNING: A DEVELOPMENT OF LEARNING MATERIALS
}

\author{
Yenny Suzana1, Sabaruddin*1, Suesthi Maharani², Zainal Abidin' \\ ${ }^{1}$ Institut Agama Islam Negeri Langsa, Indonesia \\ ${ }^{2}$ Institut Agama Islam Negeri Salatiga, Indonesia
}

\begin{tabular}{l}
\hline Article Info \\
\hline Article history: \\
Received Apr 26, 2021 \\
Revised July 13, 2021 \\
Accepted July 18, 2021 \\
\hline
\end{tabular}

Keywords:

Character,

Material development,

Mathematics learning,

Thematic

\begin{abstract}
This research is to develop mathematics teaching materials that are integrated with elementary school thematic learning. The purpose of the development is to obtain mathematics teaching materials that prioritize the local wisdom of the Acehnese people. This teaching material is helpful for fifth-grade elementary school students in which there are character values for learning mathematics. This study uses a qualitative descriptive research method with the ADDIE model development research design. This research focuses on analyzing elementary school teachers who face the problem of integrated mathematics-based character education in thematic learning, then making initial designs and developing character education-based mathematics teaching materials that are integrated into the learning theme. The results showed that character education-based mathematics teaching materials were compatible with elementary students' thematic learning. Mathematics teaching materials focused on solving math problems for elementary students, integrating character values in mathematics with various themes in thematic learning by integrating each mathematics material into themes. The mathematics teaching materials developed were designed with various activities related to daily activities with straightforward language to be understood and made into a mathematical model.
\end{abstract}

Copyright $(2021$ IKIP Siliwangi. All rights reserved.

\section{Corresponding Author:}

Sabaruddin,

Department of Mathematics Education,

Faculty of Tarbiyah and Teacher Training Science,

Institut Agama Islam Negeri Langsa

Jl. Meurandeh, Langsa, Aceh 24415, Indonesia

Email: sabaruddin@iainlangsa.ac.id

\section{How to Cite:}

Suzana, Y., Sabaruddin, S., Maharani, S., \& Abidin, Z. (2021). Mathematics learning through character education based on integrated thematic learning: A development of learning materials. Infinity, 10(2), 301318.

\section{INTRODUCTION}

Primary school mathematics learning is the initial introduction to numerization and integrating abstract knowledge into real objects (Tzanakaki et al., 2014). However, in practice, mathematics learning in primary schools encountered various difficulties in reallife applications (Banda \& Kubina Jr., 2009; Dennis et al., 2016). Most of the problems 
encountered were related to students' ability to translate sentences into mathematical models (Boonen et al., 2016). The application of mathematics in life is not applied in the learning process in the class (Nasrum \& Herlina, 2019; Setiyani, Putri, \& Prakarsa, 2019; Yunianta, Putri, \& Kusuma, 2019). Mathematics books focus on solving mathematics analytically and are heavy for students (Nurharyanto \& Retnawati, 2020). The problem-solving presented does not relate to problems in the real world, so mathematics is less attractive to primary school students (Khodeir et al., 2017; Saputra et al., 2018).

Various studies in implementing mathematics learning out state that schools' learning process has not paid attention to students' needs and potential for improving students' abilities (Wijaya et al., 2019). Learning tends to be theoretical, the role of the teacher is very dominant (teacher-centered), and the communication style is in one direction (Zain et al., 2012). As a result, the learning process is limited to the transfer of knowledge that is less related to environmental learning. Students are unable to apply key concepts of knowledge to solve problems in everyday life. As a result, this condition creates a reluctance to read and write in Indonesian primary school students.

Handal and Bobis's (2004) research on teacher understanding and practice towards thematic approaches can link mathematics with real life. However, in reality, thematic learning has not been fully implemented in class. In this study, instructional, curriculum, and organizational factors were considered by teachers as obstacles in the application of thematic approaches to teaching mathematics. Broadly, the material presented in the mathematics book is not entirely thematically applicable. The completeness of the facilities and the learning environment is also influential in applying them to primary schools' mathematics learning (Haylock \& Thangata, 2007). The thematic approach is one of the learning strategies to create active, meaningful, and exciting learning (Chumdari et al., 2018; Narti et al., 2016). It also provides a framework for developing correlated concepts, a more stable learning model, and suitable students with different abilities (Handal \& Bobis, 2004).

At present, primary schools' educational practice phenomenon shows a high trend that only focuses on one subject. Learning is only aimed at instructional impact. The evaluation system is involved in reproducing information. They have not exceptionally motivated students (Nahrowi, 2019). The teacher comes to class with a book and then asks students to complete the book's exercise before explaining the lesson. Most teachers still use lesson plans at the planning stage without paying attention to students' abilities. Teachers are still less effective in using media to involve students in learning actively. Equitable education can be carried out. The education system must serve all student ages to enjoy education at least in the essential skills needed, namely reading, writing, and arithmetic (John, 2015). According to Bier et al. (2016) character education requires young people to judge what is right, pay close attention to what is right, then do what is right, even in the face of external pressure and temptations from within.

Learning activities in elementary schools are arranged based on the 2013 curriculum which implements integrated thematic learning with a scientific approach. The thematic model is applied to the first three classes (grades 1,2, and 3), while the fragmented model is applied to the next class (classes 4, 5, and 6). The thematic model is a learning model that uses themes to connect several subjects to provide meaningful experiences to students (Chumdari et al., 2018). It is also interpreted as a learning model that departs from a specific theme as a center of interest in understanding other symptoms and concepts, both from various subjects and one subject (John, 2015). This learning model starts with great ideas, essential questions, or problems in reality and has contextual meaning for students (Handal \& Bobis, 2004). Students use skills and knowledge from various subjects simultaneously to answer questions or solve problems. Thus, the thematic learning model is a learning model 
designed based on specific themes to provide students with meaningful experiences (Ekowati, Utami, \& Kusumaningtyas, 2018; Narti et al., 2016).

The application of integrated thematic learning resulted in changes in learning, changes in manuals for teachers and students. Thematic or integrated learning departs from the idea that students gain the best knowledge when learning in a coherent overall context because they can relate what they learn to the real world (Wangid et al., 2014). Thematic is one type of integrated learning model as said that integrated learning includes three types: the connected, thematic or webbed type, and integrated (Islam \& Suparman, 2019). The connected type integrates subject matter from a particular discipline. Webbed or thematic types develop material from the specific subject matter or several subject matter or scientific disciplines (Sunhaji, 2013). The integrated type combines material from several subjects or disciplines.

The development of the learning model begins with determining a specific theme and is accompanied by sub-themes' development by paying attention to the interrelationships between subjects. Themes are chosen based on negotiations between teachers and students or discussions between teachers. After the themes are determined, sub-themes are formulated. Furthermore, student learning activities are designed based on sub-themes. Information was obtained from various sources by interviewing several teachers from different schools, that thematic learning helps teachers improve the application of character in learning. However, the problem with mathematics is that to have not met the standards for fulfilling basic mathematical concepts. Meanwhile, mathematics lessons in the previous curriculum had too high a mathematical concept so that character values could not be applied in mathematics lessons (Sabaruddin et al., 2020).

Burns (2012) distinguish integrated curricula into three categories: multidisciplinary, interdisciplinary, and transdisciplinary approaches. Teachers integrate sub-disciplines in subjects in a multidisciplinary approach, such as reading, writing, and speaking in languages. Integrate history, geography, economics, and politics into interdisciplinary social science programs. In an interdisciplinary approach, teachers compile curricula from across general disciplines. For example, students learn to make wind and rain machines while learning a language simultaneously. Students learn about a particular theme concerning several related subjects. The teacher uses overlapping material on several subjects simultaneously. In a transdisciplinary approach, teachers and students discuss specific themes that are broad and cross-subject. In this study, thematic learning is included in an interdisciplinary approach. The teacher presents particular themes that are learned from diverse and related subjects.

Based on this description, it can be concluded that the application of thematic learning models in primary schools is a valuable effort to achieve student learning outcomes, both in the aspects of knowledge, skills, and values and attitudes/characters. Therefore, this study develops mathematics teaching materials that are integrated with thematic learning for fourth grade elementary school students in Langsa City. Mathematics teaching materials in accordance with the theme of the local wisdom of the Acehnese people. In addition, this mathematics teaching material can be useful for students because in it there are character values for learning mathematics. This mathematics teaching material containing local wisdom can be recommended as a solution to overcome the problems faced during the COVID-19 pandemic.

\section{METHOD}

The method used a descriptive qualitative with a development research design. The development model used the ADDIE model. The ADDIE model consists of 5 stages, namely Analysis, Design, Development, Implementation, Evaluations. The development in this 
research has reached the stages of analysis, design and development. This study analyzes the importance of developing mathematics teaching materials combined with thematic learning, planning development designs and developing mathematics teaching materials with a character education approach to thematic grade 5 elementary schools. Implementation and evaluation are reserved for further studies and recommendations from the research that has been carried out, the implementation and evaluation studies will be continued in the next period.

\subsection{Preleminary Research}

Preliminary research activities are carried out to collect information before the research is carried out, including literature studies and field studies. Literature studies are used to find the concepts, scope, supporting conditions, and the most appropriate steps to develop products. Preliminary research in the form of literature studies is carried out to analyze more depth and find relevant research literature to solve the problems found.

\subsection{Materials Development Planning}

The product development process includes the process of designing and compiling mathematics teaching materials that contain local wisdom of the Acehnese people and in which there are character values in elementary school thematic learning in Langsa City which were developed on nine themes in fifth grade. Researchers compiled the steps of teaching materials as follows: following. First, choosing KI and KD for 2013 Curriculum subjects, developing mathematics materials that instill values of logical thinking, critical, hard work, curiosity, independence, honesty, democracy and self-confidence which include the theme. Second, determine the material and formulate learning indicators in accordance with the theme. Third, determine the place of research trials for the sake of implementation and evaluation of teaching materials that have been developed.

\subsection{Initial Product Development}

Initial product development is carried out by selecting material included in character education-based mathematics teaching materials. The researchers developed the theme in fifth grade, determined the learning process by the learning material, and compiled a learning evaluation to measure whether the indicators can achieve the expected learning outcomes.

\section{RESULTS AND DISCUSSION}

\subsection{Results}

\subsubsection{Preliminary Study Results of Teaching Materials Thematic Study}

Teaching materials that are developing are mathematics teaching materials for grade 5 primary schools. The current curriculum that is currently in effect fully applies thematic learning so that all teaching materials are included in a series of themes. Assessed thematically for grade one to grade three, primary school is reasonable and very appropriate because there are many student behavior developments. However, it is different with thematic for grades four, five, and six. Most teachers consider it difficult and feel deficient in mathematics teaching material, so they need to return to mathematics lessons like the previous curriculum as stated by Halimah, S.Pd (pseudonym), one of the principals of SD Negeri in Langsa City in an interview: 
"...in grade 5 we still use thematic, but for mathematics, we use special subject teachers, because in thematic we are worried that our students will not understand mathematical concepts...."

The policy will set mathematics lessons to be considered because of concerns from various parties about students' mathematics quality. Usually, on the final exam, questions will be given with a high standard. It is feared that students will miss mathematical concepts as a whole if only by participating in thematic learning as expressed by Mr. Surya (pseudonym), a classroom teacher at a public primary school:

"...It is straightforward to teach during our thematic lessons, let alone many learning activities directly related to daily life. However, we are worried about maths lessons, math topics are concise, and there are some materials in math textbooks not included in thematic lessons..."

During the implementation of the 2013 curriculum, there were many developments and advances in character building among students. With various efforts in its application, revisions were made from various sessions, and a curriculum that was friendly to the internalization of moral values was obtained in an integrated manner. The combination of cognitive, affective, and psychomotor is effortless to apply in thematic learning; it is just that the method needs to be improved so that all elements are met and can be accepted by all groups. Many teachers' integrated thematic view has begun to seem understood, where their weak and strong sides can slowly be detected. As discussed with Mrs. Juli (pseudonym), SDIT teacher in Langsa City, as follows:

"...At the beginning of the implementation the 2013 curriculum, we were confused because all the lessons were combined in one book. We see that the subject matter is complicated and low. It is not the same as in the previous lessons. We finally got socialization several times to understand that an integrated thematic is useful as an application of learning concepts in everyday life by emphasizing the internalization of character values to students..."

From the observations made in several schools, mathematics lessons converted to themes have been carried out by primary teachers in Langsa City. Not all schools have implemented the thematic curriculum since the beginning of the 2013 curriculum; only a few schools are pilot studies, others are voluntary in their application. However, in this curriculum, the ministry made many modifications and revisions based on input from schools that became the pilot studies.

Thematic lessons for grades four, five, and six are believed by teachers to be applicable and integrated with students' character values. However, integrating with mathematics lessons have difficulties in practice. Following are the results of the initial discussion with Mrs. Husna (pseudonym), SDIT teacher in Langsa City:

"... with our thematic books, it is easy to teach and create activities related to everyday life. Character values are also easy as students are easy to work with, respect each other, discipline, understand and love the environment and several other characters. Nevertheless, we cannot be sure in maths lessons whether they are adequate and arrive at a math concept equivalent to their class because we saw that some questions at the National level were much higher and deeper. So sometimes we keep using the old math textbooks for math lessons..."

Based on several discussions that have been carried out with primary school teachers and principals in Langsa city, preliminary information was obtained that thematic learning 
in primary schools is good and can be integrated with students' character values. However, mathematics still needs to be explicitly developed and in-depth, like teaching materials that can combine themes and math lessons. To produce teaching materials that meet thematic and sufficient elements of mathematical concepts. There is no concern among teachers about the academic achievement of their students, especially in mathematics. Moreover, to prepare students for the national level examinations and several other tests carried out correctly.

Two steps were taken at the preliminary study stage, namely information gathering, and planning. In the information-gathering step, activities are carried out by field surveys and literature studies. The field survey was conducted to obtain information about the state and availability of teaching materials used by teachers and students in the mathematics learning process. Activities carried out at this stage include field observations and interviews with mathematics teachers. The results of the field survey obtained information that the learning process is still teacher-centered.

The teacher begins the lesson by directly providing the material, which does not allow students to understand the material. In addition to the learning process, what is observed from this observation stage is that the teaching materials used in learning are only textbooks provided by the government and worksheets from private publishers. In addition to observation, other preliminary study activities are interviews with mathematics teachers. The results show that the teacher has never given a test that demonstrates mathematical reasoning and communication skills. The teacher has never carried out thematic learning. Private teaching mathematics textbooks use teaching materials from the government and private publishers. Literature studies in this research include thematic studies, studies of mathematical reasoning skills, studies of mathematical communication skills, and study of teaching material development models.

\subsubsection{Study of Mathematics Teaching Materials}

Mathematics was implemented before the 2013 curriculum and is still being applied in many schools even though it implements thematic learning. Mathematics lessons in primary schools face many challenges in the learning process, such as many classroom teachers who do not master mathematics well, as was expressed by Mrs. Sugiarti (pseudonym), a teacher at the Public Primary School in Langsa City:

"...We miss certain material because it is difficult to explain, knowing that I am not an alumnus of mathematics education or PGSD. I used to study SPG, and then in 2007, I continued to S1 historically. However, I often work as a classroom teacher, and I have no problem with other subjects, but I find it difficult"

It is not only the teaching materials that are difficult for the teacher, but also many other difficulties, such as being difficult to apply daily. In the mathematics textbook, no character value content will be achieved. Mathematics teaching material tends to be very complicated. Many concepts must be understood by teachers and students but are not applicable in everyday life. The following is the statement of a teacher in an interview with Mrs. Rosnidar (pseudonym), a Public MI teacher in Langsa City:

"...We often try to relate mathematics to life. However, it is not easy to give an example. I also see that no character value will be achieved in mathematics teaching materials-furthermore, more focus on finding answers to the textbook's questions. So I do not dare to spend time applying character in maths lessons..." 
The same thing was also expressed by Mr. Alamsyah (pseudonym), a private primary school teacher in Langsa City.

"...I have not applied many aspects to mathematics in my life, especially in teaching. I am worried that I will not be able to finish the existing syllabus. If I teach by doing activities outside the classroom, it will take much time, and I also rarely use the time to study mathematics to do according to my daily life. Some materials are difficult to miss because they are difficult to explain to students..."

Based on initial conversations with primary school teachers in Langsa City, it can be explained that mathematics lessons need to be developed so far. In line with the 2013 curriculum and its revision emphasizes students' character and competence, modifications are made to integrate lessons with character so that lessons can be applied to daily life and can foster good attitudes towards students, especially in mathematics lessons. The development of friendly and easy teaching materials for children is also the dream of parents, as stated by Ibu Susi (pseudonym), one of the parents of primary school students in Langsa City:

"... we hope that there will be teaching materials that are easy to explain because when we do children's assignments, we do not bother asking people anymore. In the meantime, we have much material that we cannot help to explain. In thematic lessons, it is straightforward and understandable, but I am worried that later on the children will master math teaching materials during the final tests and exams ..."

Mathematics feels alive and benefits students if what they learn is directly related to daily practice. With the perceived benefits of learning mathematics, students will be more enthusiastic and enthusiastic about learning, making it easier for teachers in the learning process. Mathematics is expected to contribute to improving students' understanding of everyday applications. In addition to increasing student competence, it is also expected that they have good character. Mathematics also plays an essential role in improving student character. Therefore, the development of thematic-based mathematics teaching materials is significant. Because it will stand in the middle of both, lessons with mathematical concepts are deliberate on various themes that meet the elements of character values that will be grown. The character values that are grown are integrated with mathematics lessons with the various activities presented.

The results of discussions with several teachers and school principals can be used as the basis for the development of this teaching material is essential. Several vital aspects must be fulfilled, such as competence and character values to be achieved. In the FGD, there were also some problems in general in schools at this time. In the learning process, many teachers were not good at math. There were lots of mathematics books, so that teachers were chasing material. They were not applicable in everyday life and had nothing to do with character values.

In comparison, thematic problems are obtained for grades four, five, and six. In this class, mathematics should be presented in detail and in-depth, but in a very light thematic, and it is feared that it will become a problem during the national exam. In this case, the FGD expects that there will be a modification of teaching materials that meet the two elements sufficiently in the teaching material and can be applied in life and integrated with students' character values. 


\subsubsection{Teaching Material Development}

Thematic Mathematics Learning Module grade5 Elementary School based on Character Educationbelow contains material exposure, illustrations, examples of solving practice questions, practice questions, and student activities packaged attractively to become more enjoyable for students. This module's distinctive feature is that its content is contextual and realistic. It is close to the students in terms of language, and the pictures also include several teachings of culture and good character. It is hoped that the mathematics teaching material in the form of a Thematic Mathematics Learning Module Class 5 SD based on character education can be accepted and used by students to explore abilities and get to know the natural surroundings well. So, the author humbly accepts suggestions and criticisms that can build and hopes that the writer will improve the preparation of this book.

This teaching material focuses on finding common ground from thematic and mathematics lessons to correctly improve character and understanding of mathematical concepts. So that students can find the purpose of learning mathematics through applications in everyday life. Some essential aspects in this research are the book's attractive image design, the use of language, the students' experience-based question, the explanation of the objectives and benefits of learning, the character values achieved, and the problem-solving cases moral messages for students.

\subsubsection{Book cover}

Mathematics textbooks are designed with mathematical characteristics and show an impression of seriousness in understanding mathematical concepts. In this study, the cover is designed in a light and straightforward form so that it does not impress mathematics on purpose, but mathematics will be applied lightly, even accidentally. The Figure 1 are some differences of the book cover before being developed and after being developed.

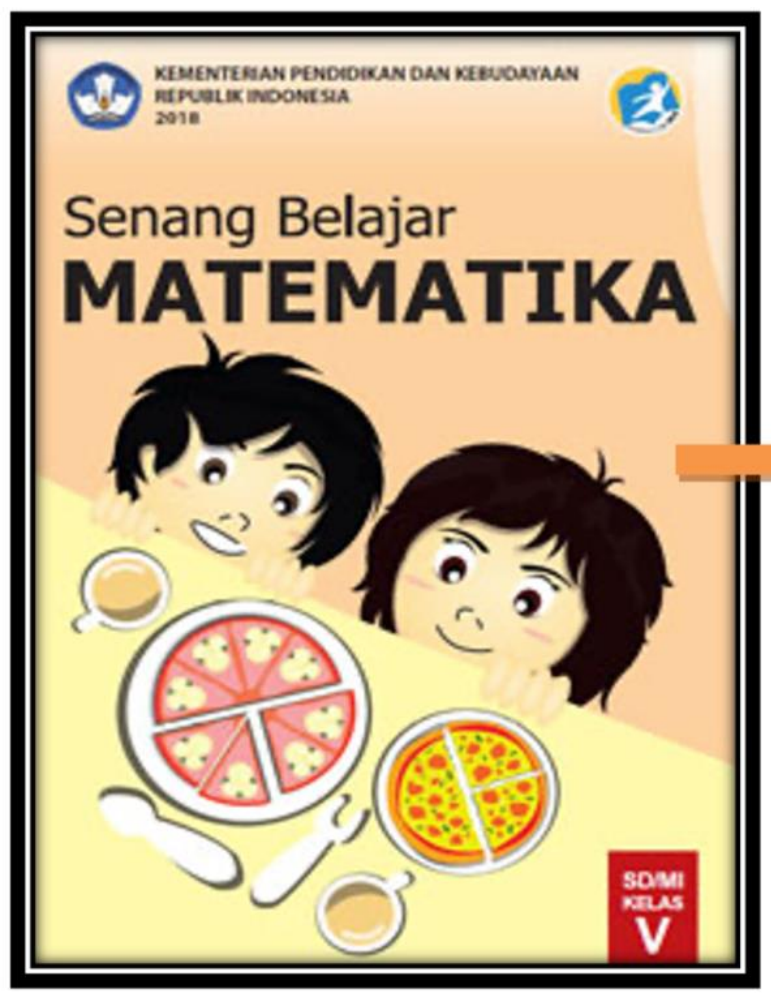

(a)

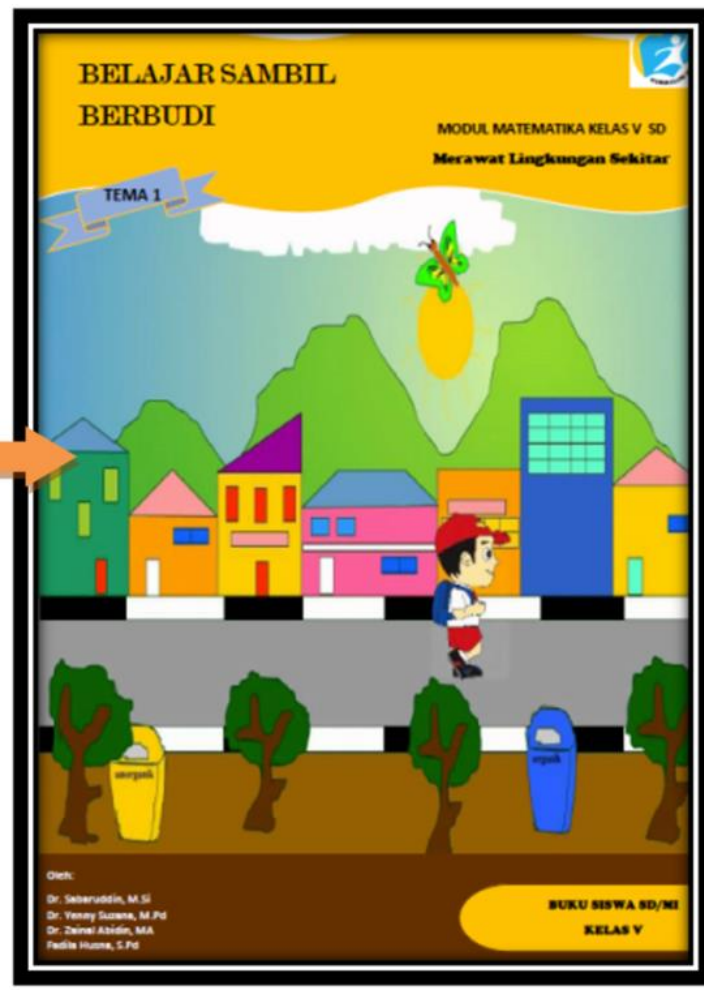

(b)

Figure 1. Cover design before and after development 
Based on Figure 1, the development can be seen. The 5th-grade mathematics textbook shows the numeration of objects and messages only through less visible writing and coloring. The development carried out in this research is to provide a more visible inheritance and an image as if it provides an important message to protect the environment. The development is related to the theme so that the cover image of the book shows the theme being studied. The identity of the book can be seen from the mathematics textbook that is clear and understandable. In contrast, in the thematic book, the book's identity based on the theme studied does not contain explanations of mathematics material. In the teaching materials developed, it is clear that the themes being studied and the mathematics lessons are obvious. The message should give an impression to students, and the goals should be better in behavior and advance in mathematics ability.

\subsubsection{Preface and book instructions}

The development of teaching materials is explained by the use and uniqueness of the book's contents through the introduction. Clear instructions that make it easier for book users to understand the purpose of using this teaching material. This teaching material can also be used personally by students at home without teacher guidance because it is designed with easy language and examples. For parents who assisted their children in learning mathematics during the pandemic, this book can be easily understood and do not need to worry about their children's mathematics achievements. Mathematics textbooks do not explain instructions for use, and many teaching materials are difficult and less applicable in everyday life. In contrast, the guidebook theme is also less related to complex mathematics teaching material.

\subsubsection{Material presentation}

This mathematics teaching material starts with natural pictures according to the theme, examples of themes of caring for the surrounding environment, and sub-themes of objects of natural surroundings. The pictures presented are often observed by students in everyday life. Students easily observe the mathematical values such as how many are entered and the geometry positions so that mathematical concepts can be explained correctly and efficiently. After students can accept it, an explanation is presented with examples of nature cases by modeling mathematics. The example presented provides a moral message to students regarding the theme being presented, such as caring for the surrounding environment, fostering an attitude of love for the environment, and keeping the environment clean with mathematics (see Figure 2). 


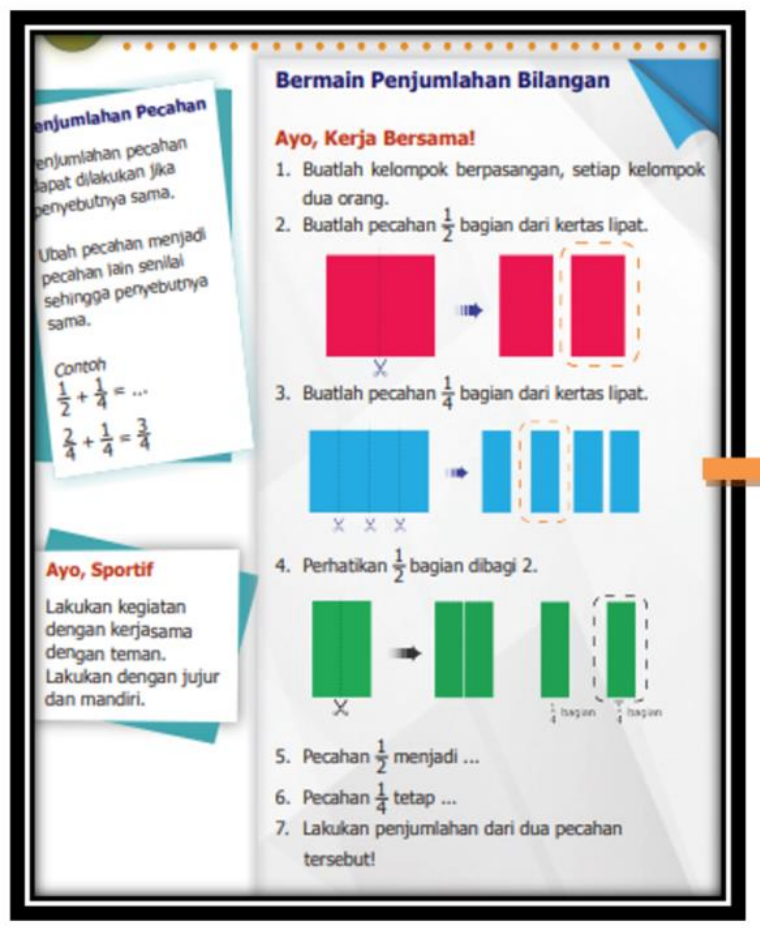

(a)

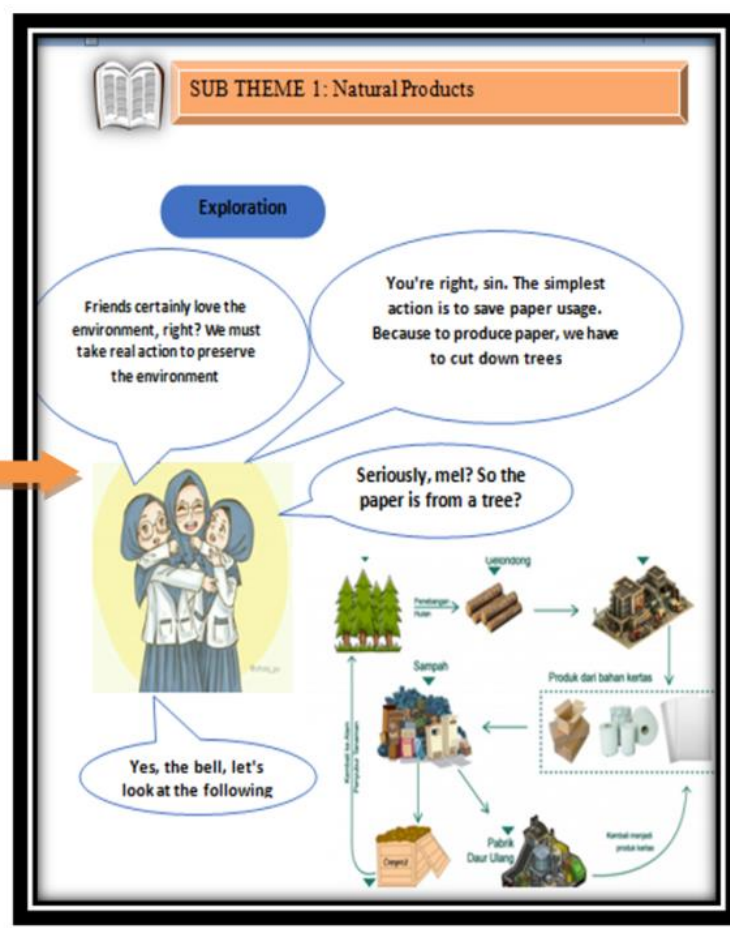

(b)

Figure 2. Description of the presentation of the material

Based on Figure 2, it can be seen the differences in the presentation of teaching materials. In Figure 2a, the mathematics material is presented directly with a rigid and mathematical image. Whereas in Figure $2 b$, teaching materials have been developed with presentation through images related to caring for the surrounding environment and subthemes of natural products. Pictures and descriptions of stories show that students must care for their environment with mathematical and fun activities so that learning becomes fun.

\subsubsection{Student worksheet}

After presenting the teaching material, the teaching material is given space for students to carry out worksheet activities or student worksheets to determine whether students already understand the material presented and can actualize it in real examples. In mathematics books, in general, examples of problems are presented with textual solutions with mathematical concepts. In developing this teaching material, student worksheets are presented with examples of activities related to the theme and entering the character values to be achieved (see Figure 3). 


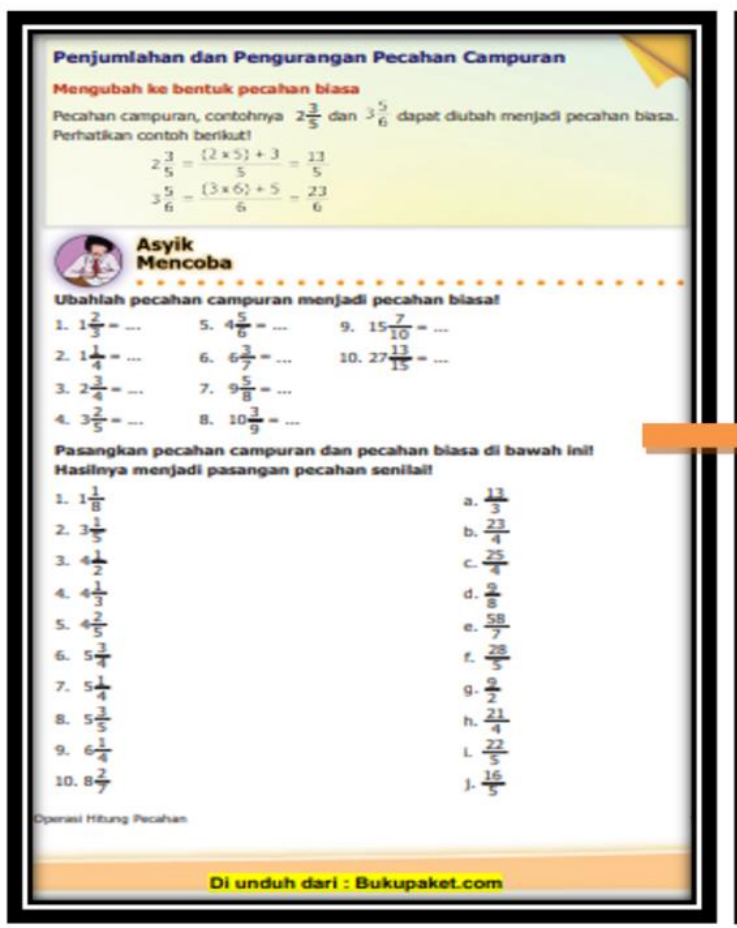

(a)

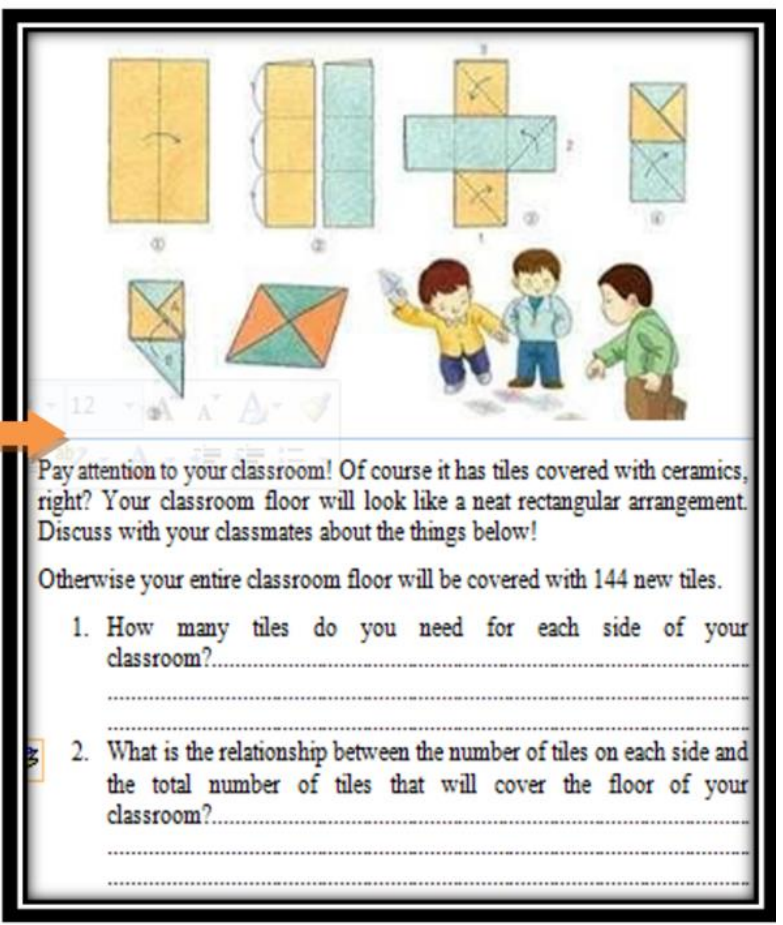

(b)

Figure 3. Students' worksheet

Based on Figure 3, it can be seen the differences in student worksheets. Figure 3a shows the student worksheets in the class 5 mathematics book. The student worksheets can be seen with questions related to the teaching material. Meanwhile, there is no application in life, and no moral message is delivered. Whereas in Figure 3b, the development carried out is by providing examples of student work with questions related to the theme being studied and applying mathematics in everyday life.

\subsubsection{Group workspace}

The development of this teaching material also pays attention to group workspaces. It provides work steps and a place to provide reports on mathematical activities carried out by the theme being studied. Whereas in the previous mathematics books, there was no room for discussion and no problems that students had to solve collectively (see Figure 4).
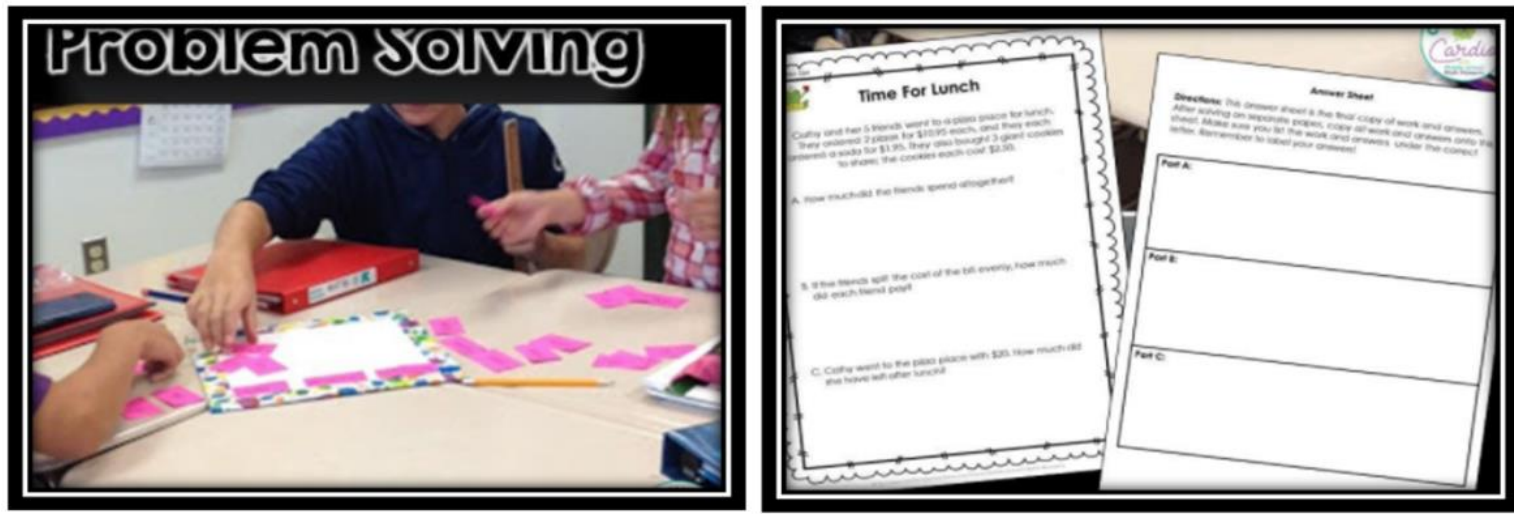

Figure 4. Student collaboration sheet with the team 
Based on Figure 4, it can be seen that in the development of mathematics teaching materials, students are also given space to carry out discussions in groups. In preparation for the discussion, students are also given several instructions on working and steps for problemsolving. In this way, some character values can be applied, such as collaborating with friends, cooperating, respecting opinions, and having a sense of responsibility towards tasks and teams. Then it is hoped that students can share experiences and provide explanations to friends who do not understand.

\subsubsection{Formative test}

Development is carried out up to the formative test. Formative test questions usually meet the elements of indicators and competency standards to be achieved. In the formulation of the questions, an analysis stage of the students 'thinking is developed to make it easier to map students' competencies and achievements. In the math book, formative test questions are arranged with no space to solve them. Whereas in the development of this teaching material, questions were arranged with several levels of student thinking processes ranging from low to high levels and given space to solve these questions. The questions are presented by paying attention to the character elements to be achieved (see Figure 5).

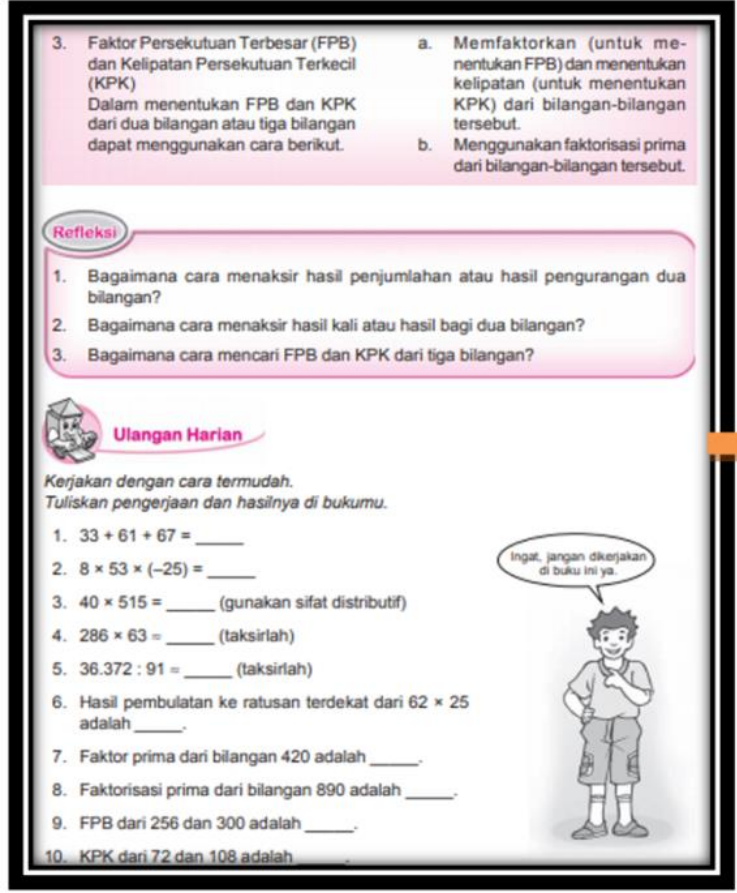

(a)

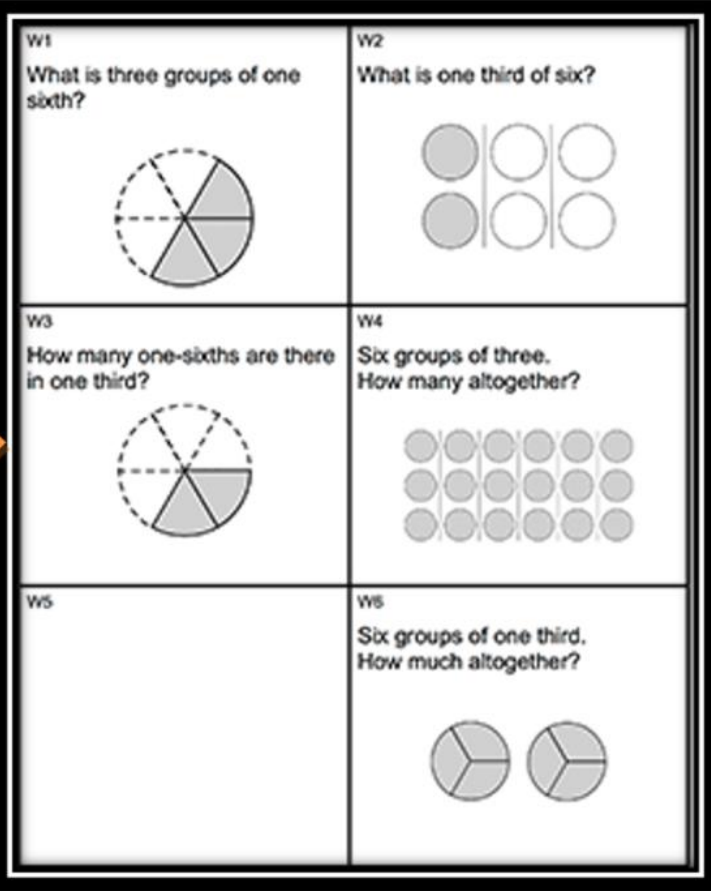

(b)

Figure 5. Examples of formative test questions

Based on Figure 5, the differences in mathematics textbooks and the development of teaching materials can be seen. Teaching materials modified in Figure $5 \mathrm{~b}$ provide space for students to answer directly. The questions presented invite students to think creatively by modeling mathematics from stories that contain character values. Each pillar presented is related to the theme being studied to absorb and solve problems easily. Figure 6 describes student worksheets with patterns of helping each other solve problems related to everyday life themes. 


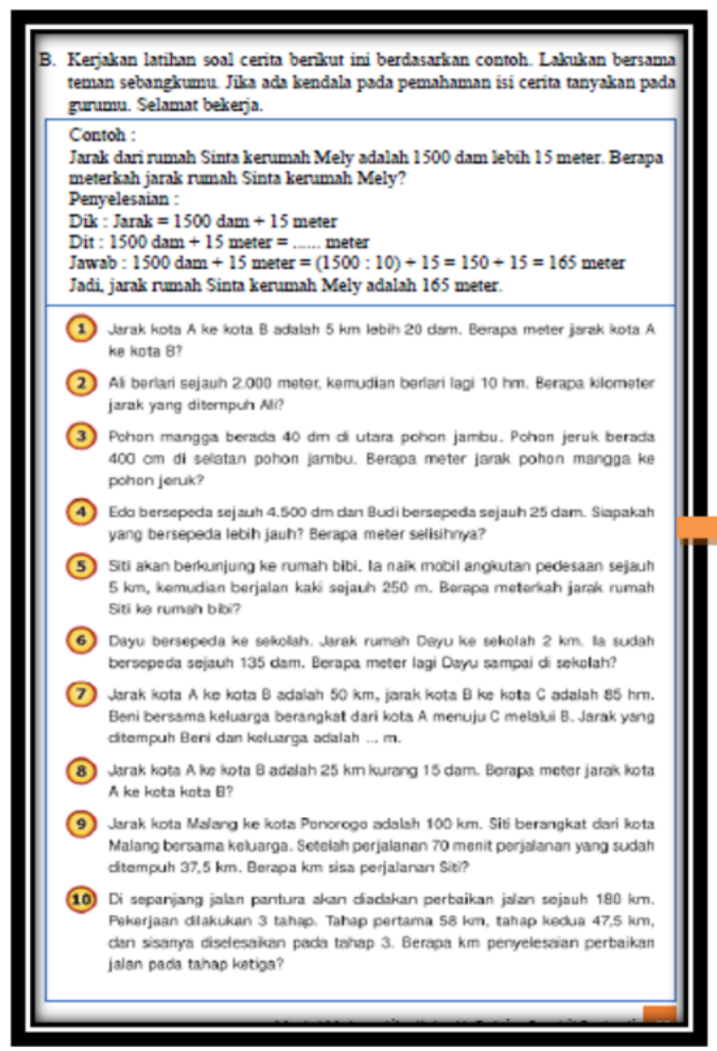

(a)

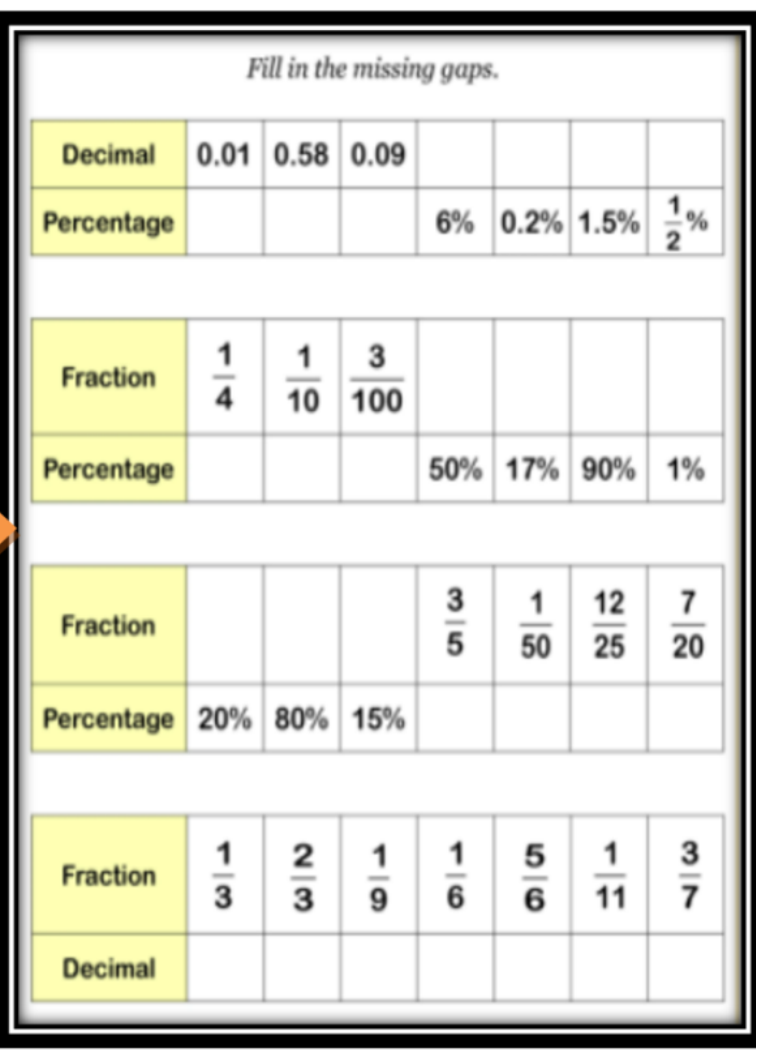

(b)

Figure 6. Examples of student worksheets in test form

\subsection{Discussion}

Based on field data, it is found that thematic learning applied in schools helps and makes it easier for teachers to apply character values that have a specific relationship between the subject matter and the students' natural experiences. In line with Ekowati et al. (2018) state that the main characteristic of thematic learning in primary school combines lessons with a contextual framework and deepening character values. As Hasrawati (2016) expressed, thematic learning also provides direct experience for students to absorb lessons related to life and learning to be interesting to follow. Thus, increasing learning motivation and facilitating classroom management. It was obtained information that the teacher was ready to enact the new law. Many also welcomed thematic learning and were ready to implement it even though various ways were taken to get instructions. This finding is in line with the findings of Wangid et al. (2014) that primary school teachers' readiness in implementing thematic learning in the 2013 curriculum is perfect. Based on this percentage, the teacher's readiness from behavioral readiness is also very good, although teachers need to carry out training from various sources independently.

Moreover, it is hoped that the readiness of the teacher can increase student achievement through thematic learning (Riwanti \& Hidayati, 2019). The development of the thematic learning module based on character education for class $\mathrm{V}$ elementary school has had a good impact on students where students can slowly get used to having the desired attitude or character education values. Experimental where the implementation of integrated learning is beneficial and the student response to it is very good. Chumdari et al. (2018) concluded in their research that the thematic learning model in primary schools could be done well, but students' learning activities are less than optimal. It is due to conventional 
teacher-centered methods that emphasize the active role of teachers rather than students. It needs to be improved by promoting innovative learning models that allow students to carry out learning activities, such as object/environment manipulation, discussion activities, and group activities with fellow students.

Thematic teaching materials can improve students' abilities and character. As expressed by Utami and Mustadi (2017), teaching materials developed based on thematic can provide convenience and improve abilities and improve student character, tie learning motivation, and increase student achievement. The development of teaching materials is essential to do in order to adapt to the conditions and characteristics of students, and development will also provide innovations and strategies that facilitate the absorption of learning. The development of teaching materials and teaching aids is carried out based on necessary modifications so that what is already there is to be better and useful and right on target in the application in life (Wulandari \& Prasetyaningrum, 2018).

Mathematics lessons need development, considering that the thematic concepts are still low and mathematics is too high. It is necessary to combine both of them to produce suitable teaching materials. The development of teaching materials related to direct experience has a very positive impact on mathematics (Putri, Hasratuddin, \& Syahputra, 2019). Improving character and motivating students are ways to solve various mathematical problems. The preparation and development of textbooks would help teachers and students learn the material in a particular lesson (Chumdari et al., 2018). Textbooks play a critical role in the improvement and content of thematic and mathematics curricula. All forms of theoretical interpretation can be applied in the development of teaching materials.

In terms of teacher background, this study found much diversity, such as education level, the field of study, teaching experience, and teacher certification. Teacher background and education level are very influential on teacher interaction skills in learning. It is in line with Iswadi and Richardo (2018) research findings that the background level of education and teaching experience of a teacher can affect teachers' professional ability in learning interactions. The teacher background problem is also in line with the Mutakin (2013), which states that "teacher competence and teacher background together positively influence the performance of primary school teachers."

Firdaus's findings (2014) showed that teachers' level of education, training, and teaching experience could be used to predict teacher professionalism in teaching. Rakib et al. (2016) also argued that "training partially positively and significantly affects teacher professionalism. Teaching experience partially has a positive and significant effect on teacher professionalism, and training and teaching experience simultaneously have a positive and significant effect on teacher professionalism". The sad thing is that many teachers do not get the opportunity to improve their competence through training. Because so far, the government has provided minimal opportunities for funding for teacher training.

Based on the preliminary observations from several primary schools in Langsa City, there are still many times that need to be considered. More than $30 \%$ of primary schools do not have adequate facilities and infrastructure so that it is challenging to implement thematic learning. The environment is a slum, the learning room lacks facilities, inadequate learning media, materials for experiments are not available, the library is incomplete, and even books are not available. There are no laboratories available at the school. It is a major obstacle in the learning process, especially in implementing thematic learning. Similar findings have also been highlighted by Kurniawan's (2017) research that the importance of planning from school leaders to plan facilities and infrastructure. This study also concludes that "one of the efforts that can be made to improve learning effectiveness is by improving facilities and infrastructure for increasing teacher competence." 
The development of mathematics teaching materials is needed because teachers have several obstacles in using thematic books. As the results of research conducted by Kurbaita et al. (2013), problems such as the teacher have not been able to identify the basic competencies of several subjects that can be integrated into one learning theme. Also, thematic books that have been well prepared also experience problems in their use due to many unsupportive things such as facilities and infrastructure, school environment, teacher training, and learning media. Sukiniarti (2014) showed that the obstacles experienced include "most teachers consider it more challenging to develop thematic lesson plans than lesson plans in the field of study. Especially in determining methods and preparing evaluation questions; all teachers find it difficult to determine the media of each predetermined theme; Most of the teachers to determine the theme with the right method, still have to discuss it with fellow teachers.

The development of teaching materials that occurs is combining integrated thematic mathematics lessons in primary schools. Mathematics lessons need to be modified so that mathematics lessons do not feel challenging for students; by providing examples and applications in everyday life, students easily accept mathematics. It is in line with the research conducted by Narti et al. (2016) and Ahsani (2020) that thematic learning plays an essential role in increasing student attention, learning activities, and understanding of the material. As learning is more student-centered, it provides students with hands-on experience. The current concept offers a flexible range of topics. Besides, learning outcomes can be developed according to student interests and needs. Thematic learning plays an important role in increasing students' attention, learning activities, and understanding of the material. As learning is more student-centered, it provides students with hands-on experience. The current concept offers a flexible range of topics. Also, learning outcomes can be developed according to student interests and needs.

Teaching materials that have been developed include cover designs that attract students to open books, complete mathematics material so that all mathematical content can be learned by students but by combining them with them. Each student teaching material is invited to carry out learning activities according to the theme being carried out. In addition to modification in terms of student worksheet material, it is also modified. Up to the formative exam, it is attractive to make students not bored and not find it difficult to solve them (Putri et al., 2019). The results show that learning materials based on a realistic mathematics education approach are important things that need to be considered to maximize student mathematics learning achievement. Thus, it is expected that mathematics teachers are looking for mathematics. Learning uses teaching materials based on a realistic mathematics education approach.

\section{CONCLUSION}

Based on the results of the development, it is obtained that mathematics teaching materials contain local wisdom of the Acehnese people and in which there are character values of logical thinking, critical, hard work, curiosity, independence, honesty, democracy and self-confidence. This mathematics teaching material was developed for fifth grade students in thematic learning at Elementary Schools. There are character values like learning mathematics. Student worksheets are available in the teaching materials for students to solve problems, there is also space for students to make reports on their work in groups. Mathematics teaching materials containing local wisdom are easily understood by students and are appropriate to be recommended as teaching materials during a pandemic to make students strong and hardworking. 


\section{REFERENCES}

Ahsani, E. L. F. (2020). Analisis bahan ajar kurikulum 2013 berbasis multiple intelligence kelas IV. Elementary: Islamic Teacher Journal,8(1), 19-36. https://doi.org/10.21043/elementary.v8i1.7398

Banda, D. R., \& Kubina Jr, R. M. (2009). Increasing academic compliance with mathematics tasks using the high-preference strategy with a student with autism. Preventing School Failure: Alternative Education for Children and Youth, 54(2), 81-85. https://doi.org/10.1080/10459880903217564

Bier, M. C., Sherblom, S. A., Berkowitz, M. W., \& Coulter, B. (2016). The ways character strengths support $\mathrm{K}-8$ mathematics and the common core state standards. Journal of Character Education, 12(1), 35-53.

Boonen, A. J., de Koning, B. B., Jolles, J., \& Van der Schoot, M. (2016). Word problem solving in contemporary math education: A plea for reading comprehension skills training. Frontiers in psychology, 7, 191. https://doi.org/10.3389/fpsyg.2016.00191

Burns, M. S. (2012). New views into the science of educating children with autism. Phi Delta Kappan, 94(4), 8-11. https://doi.org/10.1177/003172171209400403

Chumdari, C., Anitah, S. A. S., Budiyono, B., \& Suryani, N. N. (2018). Implementation of thematic instructional model in elementary school. International Journal of Educational Research Review, 3(4), 23-31. https://doi.org/10.24331/ijere.424241

Dennis, M. S., Sorrells, A. M., \& Falcomata, T. S. (2016). Effects of two interventions on solving basic fact problems by second graders with mathematics learning disabilities. Learning Disability Quarterly, 39(2), 95-112. https://doi.org/10.1177/0731948715595943

Ekowati, D. W., Utami, I. W. P., \& Kusumaningtyas, D. I. (2018). Analisis penggunaan media pembelajaran tematik di SD Muhammadiyah 9 Kota Malang. JINoP (Jurnal Inovasi Pembelajaran), 4(1), 17-25. https://doi.org/10.22219/jinop.v4i1.4906

Firdaus, D. (2014). Pengaruh tingkat pendidikan, pelatihan, dan pengalaman mengajar terhadap profesionalitas guru di Madrasah Tsanawiyah Negeri Kediri 2. Didaktika Religia, 2(2), 159-182. https://doi.org/10.30762/didaktika.v2i2.147

Handal, B., \& Bobis, J. (2004). Teaching mathematics thematically: Teachers' perspectives. Mathematics education research journal, 16(1), 3-18. https://doi.org/10.1007/BF03217388

Hasrawati, H. (2016). Perangkat pembelajaran tematik di SD. AULADUNA: Jurnal Pendidikan Dasar Islam, 3(1), 37-49.

Haylock, D., \& Thangata, F. (2007). Key concepts in teaching primary mathematics. London: SAGE Publications Ltd. https://doi.org/10.4135/9781446214503

Islam, M. S., \& Suparman, S. (2019). Design development of interactive mathematics learning media based on character education using Macromedia Flash. International Journal of Scientific \& Technology Research, 8(12), 2855-2859.

Iswadi, I., \& Richardo, R. (2018). Pengaruh latar belakang bidang studi, tingkat pendidikan dan pengalaman mengajar terhadap kemampuan profesional guru pada SMA Kartika XIV 1 Banda Aceh. Genta Mulia: Jurnal Ilmiah Pendidikan, 8(2), 27-40. 
John, Y. J. (2015). A" New" Thematic, integrated curriculum for primary schools of Trinidad and Tobago: A paradigm shift. International journal of higher education, 4(3), 172187. https://doi.org/10.5430/ijhe.v4n3p172

Khodeir, N., Wanas, N., Elazhary, H., \& Hegazy, N. (2017). Addressing student misinterpretations of story problems in MAST. In 2017 Intl Conf on Advanced Control Circuits Systems (ACCS) Systems \& 2017 Intl Conf on New Paradigms in Electronics \& Information Technology (PEIT) (pp. 204-211). IEEE. https://doi.org/10.1109/ACCS-PEIT.2017.8303042

Kurbaita, G., Zulkardi, Z., \& Siroj, R. A. (2013). Pengembangan buku ajar matematika tematik integratif materi pengukuran berat benda untuk kelas I SD. KREANO, Jurnal Matematika Kreatif-Inovatif, 4(1), 1-10.

Kurniawan, N. (2017). Pengaruh standart sarana dan prasarana terhadap efektifitas pembelajaran di TK Al-Firdaus. Jurnal Warna: Jurnal Pendidikan Dan Pembelajaran Anak Usia Dini, 2(2), 14-26. https://doi.org/10.24903/jw.v2i2.191

Mutakin, T. Z. (2013). Pengaruh kompetensi, kompensasi, dan latar belakang terhadap kinerja guru. Formatif: Jurnal Ilmiah Pendidikan MIPA, 3(2), 145-156. https://doi.org/10.30998/formatif.v3i2.122

Nahrowi, M. (2019). Pengembangan model penilaian autentik dalam pembelajaran tematik berbasis higher order thinking skill (HOTS) pada madrasah ibtidaiyah di kecamatan Gebog kabupaten Kudus. Elementary : Islamic Teacher Journal, 7(2), 279-298. https://doi.org/10.21043/elementary.v7i2.6005

Narti, Y., Setyosari, P., Degeng, I. N. S, \& Dwiyogo, W. D. (2016). Thematic learning implementation in elementary school (phenomenology studies in Pamotan SDN 01 and 01 Majangtengah Dampit Malang). International Journal of Science and Research, 5(11), 1849-1855.

Nasrum, A., \& Herlina, H. (2019). Developing of calculus teaching materials based on audiovisual. Infinity Journal, 8(2), https://doi.org/10.22460/infinity.v8i2.p209-218

209-218.

Nurharyanto, D. W., \& Retnawati, H. (2020). The difficulties of the elementary school students in solving the mathematical narrative-type test items. Jurnal Prima Edukasia, 8(1), 29-39. https://doi.org/10.21831/jpe.v8i1.29969

Putri, S. K., Hasratuddin, H., \& Syahputra, E. (2019). Development of learning devices based on realistic mathematics education to improve students' spatial ability and motivation. International Electronic Journal of Mathematics Education, 14(2), 393400. https://doi.org/10.29333/iejme/5729

Rakib, M., Rombe, A., \& Yunus, M. (2016). Pengaruh pelatihan dan pengalaman mengajar terhadap profesionalitas guru (Studi pada guru IPS terpadu yang memiliki latar belakang pendidikan dalam bidang pendidikan ekonomi). Jurnal Ad'ministrare "Jurnal Pemikiran Ilmiah dan Pendidikan Administrasi Perkantoran", 3(2), 137148.

Riwanti, R., \& Hidayati, A. (2019). Pengembangan modul pembelajaran tematik berbasis pendidikan karakter di kelas V sekolah dasar. Jurnal Basicedu, 3(2), 572-581. https://doi.org/10.31004/basicedu.v3i2.41 
Sabaruddin, S., Suzana, Y., Abidin, Z., \& Juliana, J. (2020). Pembelajaran matematika dan internalisasi nilai karakter dalam pembelajaran tematik. Jurnal Pendidikan Matematika Universitas Lampung, 8(3),

168-181. https://doi.org/10.23960/mtk/v8i2.pp168-181

Saputra, E., Wahyudin, W., \& Dahlan, J. A. (2018). The enhancement of spatial levels reviewed from students' cognitive styles. Journal of Physics: Conference Series, 1028(1), 012093. https://doi.org/10.1088/1742-6596/1028/1/012093

Setiyani, S., Putri, D. P., \& Prakarsa, D. (2019). Designing Camtasia software assisted learning media toward students' mathematical comprehension in numeral material. Infinity Journal, 8(2), https://doi.org/10.22460/infinity.v8i2.p143-156

143-156.

Sukiniarti, S. (2014). Kendala penerapan pembelajaran tematik di kelas rendah sekolah dasar. Perspektif Ilmu Pendidikan, 28(2), 120-128. https://doi.org/10.21009/PIP.282.6

Sunhaji, S. (2013). The impementation of integrated learning in the islamic religious educationto raise the faith devotion of the students of state senior high schools in Purwokerto. Dewantara, 1(1), 58-67.

Tzanakaki, P., Grindle, C. F., Saville, M., Hastings, R. P., Hughes, J. C., \& Huxley, K. (2014). An individualised curriculum to teach numeracy skills to children with autism: programme description and pilot data. Support for Learning, 29(4), 319-338. https://doi.org/10.1111/1467-9604.12069

Utami, K. N., \& Mustadi, A. (2017). Pengembangan Perangkat Pembelajaran Tematik Dalam Peningkatan Karakter, Motivasi, Dan Prestasi Belajar Siswa Sekolah Dasar. Jurnal Pendidikan Karakter, 7(1), 14-25. https://doi.org/10.21831/jpk.v7i1.15492

Wangid, M. N., Mustadi, A., Erviana, V. Y., \& Arifin, S. (2014). Kesiapan guru SD dalam pelaksanaan pembelajaran tematik-integratif pada kurikulum 2013 di DIY. Jurnal Prima Edukasia, 2(2), 175-182. https://doi.org/10.21831/jpe.v2i2.2717

Wijaya, A., Retnawati, H., Setyaningrum, W., Aoyama, K., \& Sugiman, S. (2019). Diagnosing students' learning difficulties in the eyes of Indonesian mathematics teachers. Journal on Mathematics Education, 10(3), 357-364. https://doi.org/10.22342/jme.10.3.7798.357-364

Wulandari, S., \& Prasetyaningrum, S. (2018). Media Stamp Game untuk Meningkatkan Kemampuan Berhitung Anak Slow Learner di Sekolah Dasar. Psympathic: Jurnal Ilmiah Psikologi, 5(2), 131-148. https://doi.org/10.15575/psy.v5i2.2977

Yunianta, T. N. H., Putri, A., \& Kusuma, D. (2019). Development and comparison of mathematic mobile learning by using exelearning 2.0 program and MIT inventor 2. Infinity Journal, 8(1), 43-56. https://doi.org/10.22460/infinity.v8i1.p43-56

Zain, S. F. H. S., Rasidi, F. E. M., \& Abidin, I. I. Z. (2012). Student-centred learning in mathematics constructivism in the classroom. Journal of International Education Research (JIER), 8(4), 319-328. https://doi.org/10.19030/jier.v8i4.7277 